\title{
Pengaruh Technology Acceptance Factors, Website Service Quality, dan Specific Holdup Cost, terhadap Loyalitas Pelanggan pada Platform Shopee.co.id (Studi pada Mahasiswa Politeknik Kotabaru)
}

\author{
Dayat Ikhsan Hajati \\ Politeknik Kotabaru \\ Email : diksan.poltek.ktb@gmail.com
}

\begin{abstract}
The aims of this study were to analyze the significant and positive effect of technology acceptance factor, website service quality, specific holdup cost on customers' loyalty partially and simultaneously. The population were Polytechnic of Kotabaru students with 95 people as the samples by purposive sampling technique. The method of data analysis used multiple linear regression. The results showed that 1) there was no significant effect technology acceptance factors on customers' loyalty partially but has a positive effect, 2) there was negative and no significant effect website service quality on customers' loyalty partially, 3) there was positive and significant effect specific holdup cost on customers' loyalty partially, 4) there were positive and significant effect on technology acceptance factors, website service quality, specific holdup cost simultaneously.
\end{abstract}

Keywords: Technology Acceptance Factors, Website Service Quality, Specific Holdup Cost, Customer Loyalty

Abstrak

Penelitian ini bertujuan untuk menganalisis pengaruh signifikan technology acceptance factor, website service quality, specific holdup cost terhadap loyalitas pelanggan secara parsial dan secara simultan. Populasi dalam penelitian ini adalah mahasiswa Politeknik Kotabaru dengan sampel sebanyak 95 orang menggunakan teknik purposive sampling. Teknik analisis data dalam penelitian ini menggunakan analisis regresi linier berganda. Hasil penelitian ini menunjukan bahwa 1) tidak terdapat pengaruh signifikan Technology Acceptance Factors terhadap loyalitas pelanggan secara parsial namun memiliki bentuk pengaruh yang positif, 2) tidak terdapat pengaruh signifikan Website Service Quality terhadap loyalitas pelanggan secara parsial dan memiliki bentuk pengaruh yang negative, 3) terdapat pengaruh signifikan dan positif Specific Holdup Cost terhadap loyalitas pelanggan secara parsial, 4) terdapat perngaruh signifikan dan positif Technology Acceptance Factors, Website Service Quality, Specific Holdup Cost terhadap loyalitas pelanggan secara simultan.

Kata kunci: Technology Acceptance Factors, Website Service Quality, Specific Holdup Cost, Loyalitas Pelanggan

(C) 2020 Jurnal Riset Inspirasi Manajemen dan Kewirausahaan

\section{PENDAHULUAN}

Pada era globalisasi saat ini, dimana perkembangan teknologi informasi berkembang dengan pesat. Dimana saat ini, semua informasi dapat diakses dengan mudah dan cepat melalui internet. Hal ini bisa dilihat dari pertumbuhan pengguna internet di Indonesia yang terus mengalami peningkatan setiap tahunnya. Internet merupakan media yang sangat penting. Internet dapat meningkatkan pendapatan masyarakat yaitu sebagai sarana promosi yang tepat untuk bisnis mereka, sehingga dapat menjadi referensi dan patokan seseorang untuk mengambil keputusan yang tepat. Dengan adanya intenet, masyarakat menjadi lebih terbantu, apalagi bagi mereka yang memiliki mobilitas yang tinggi.

Online shopping merupakan sebuah cara alternatif bagi masyarakat dalam melakukan kegiatan berbelanja, dengan menggunakan internet para pelanggan dapat menghemat waktu, tenaga, dan tentunya lebih praktis bila dibandingkan dengan belanja secara tradisional. Khususnya pada waktu belakangan ini sudah mulai marak bermunculan toko online yang menawarkan berbagai macam produk dan jasanya melalui media internet.

Loyalitas Pelanggan akan terjadi apabila setiap perusahaan yang memperhatikan kepuasan pelanggan akan mendapatkan beberapa manfaat 
pokok yaitu reputasi perusahaan yang makin positif dimata pelanggan dan masyarakat, serta memungkinkan bagi perusahaan untuk meningkatkan keuntungan, maka meningkatkan harmonisnya hubungan perusahaan dengan pelanggannya serta mendorong setiap orang dalam perusahaan untuk bekerja dengan tujuan yang lebih baik. Griffin (2005) menyatakan pendapatnya tentang loyalitas pelanggan antara lain : "Konsep loyalitas lebih mengarah kepada perilaku (Behaviour) dibandingkan dengan sikap (Attitude) dan seorang konsumen yang loyal akan sepanjang waktu memperhatikan perilaku pembelian yang didefinisikan sebagai pembeli yang teratur dan diperhatikan sepanjang waktu oleh beberapa unit pembuatan keputusan".

Beberapa penelitian telah menggunakan Technology Acceptance Factors (TAF) sebagai alat ukur untuk melihat perilaku konsumen dalam melakukan pembelian online. TAF dapat berpengaruh kepada loyalitas pelanggan apabila perusahaan tersebut memberikan pelayanan yang mudah untuk dimengerti dan nyaman untuk digunakan. Sehingga peranan TAF dapat berpengaruh terhadap loyalitas pelanggan.

Loyalitas pelanggan yang merupakan salah satu faktor penentu kesuksesan yang berpengaruh pada persaingan perusahaan. Adopsi kualitas layanan sangat berpengaruh pada loyalitas pelanggan di dunia E-Commerce yaitu berupa kualitas layanan berbasis web, yang biasa disebut kualitas layanan website (Website Service Quality) adalah tingkat website dapat memfasilitasi secara efisien dan efektif untuk melakukan pembelian, penjualan, dan pengiriman baik produk dan jasa Website Service Quality (WSQ) juga dapat berpengaruh terhadap loyalitas pelanggan apabila pelayanan website yang digunakan dapat efektif dan efisien sehingga pelanggan merasa puas sehingga dikemudian hari dapat kembali menggunakan website tersebut.

Specific Holdup Cost (SHC) atau penggunaan biaya tertentu adalah suatu kegiatan dimana konsumen memerlukan suatu biaya pengeluaran selain uang seperti usaha dan waktu yang telah digunakan pelanggan untuk mencapai kebutuhannya dengan melakukan pembelian melalui media internet. Sebelum melakukan pembelian, konsumen harus melakukan pencarian dan pengenalan terhadap situs atau toko online. Sebuah biaya yang pelanggan keluarkan akan berdampak terhadap loyalitas pelanggan karena pelanggan akan kembali mengakses website tersebut karena sudah paham dengan cara penggunaan website tersebut.

\section{KAJIAN LITERATUR}

\section{E-Commerce}

Electronic Commerce (e-commerce) telah banyak didefinisikan oleh para ahli, peneliti, dan pelaku bisnis sejak kemunculan dan perkembangannya sampai saat ini. Definisi dari $e$ commerce sangat beragam, tergantung dari perspektif atau kacamata yang memanfaatkannya. Dalam berbagai literatur ditemukan definisi yang cukup beragam mengenai e-commerce, $e$ commerce sebagai proses jual-beli atau pertukaran (exchange) barang, jasa dan informasi menggunakan media jaringan komputer.

Menurut Turban beberapa definisi $e$ commerce dilihat dari beberapa perspektif komunikasi, komersial/trading, proses bisnis, service, learning, collaborative and community. Sejalan dengan definisi Turban, Laudon dana Laudon mendefinisikan e-commerce sebagai proses jual-beli barang dan jasa secara elektronik yang melibatkan berbagai transaksi menggunakan internet, jaringan dan teknologi digital lainnya.

\section{Shopee}

Shopee adalah sebuah aplikasi yang bergerak dibidang jual beli secara online dan dapat diakses secara mudah dengan menggunakan smartphone. Shopee menawarkan berbagai macam produk mulai dari fashion hingga kebutuhan sehari-hari. Pelanggan Shopee berkembang pesat hanya dalam jangka waktu 1 tahun sejak didirikan, dikarenakan baiknya sistem pelayanan yang di berikan oleh shopee.co.id, baik dalam kelengkapan produk maupun sistem pembayaran.

Saat ini ada 26 kategori yang tersedia di shopee yaitu pakaian pria, pakaian wanita, handphone dan aksesoris, kecantikan, komputer dan aksesoris, perlengkapan rumah tangga, fashion bayi dan anak, ibu dan bayi, sepatu pria, sepatu wanita, tas pria, tas wanita, jam tangan, fashion muslim, elektronik, aksesoris fashion seperti kacamata, kesehatan, hobi dan koleksi, fotografi, makanan dan minuman, olahraga dan outdoor, otomotif, voucher, buku dan alat tulis, serba serbi, souvenir dan pesta.

\section{Loyalitas Pelanggan}

Pelanggan yang loyal merupakan aset bagi perusahaan dan untuk mengetahui pelanggan yang loyal perusahaan harus mampu menawarkan produk atau jasa yang dapat memenuhi harapan pelanggan serta dapat memuaskan pelanggannya, apabila pelanggan melakukan tindakan pembelian secara berulang dan teratur maka pelanggan tersebut adalah pelanggan yang loyal. Hal tersebut 
diperkuat dengan pernyataan dari Griffin (2005), yang menyatakan bahwa karakteristik pelanggan yang loyal antara lain:

a. Melakukan pembelian secara rutin

b. Membeli diluar lini produk atau jasa

c. Merekomendasikan kepada orang lain

d. Tidak terpengaruh daya tarik pelanggan pesaing

\section{Technology Acceptance Factors}

Beberapa penelitian telah menggunakan faktor penerimaan teknologi sebagai alat ukur untuk melihat perilaku konsumen dalam melakukan pembelian online. Secara umum penelitian mengenai penerimaan teknologi informasi didasarkan pada Technology Acceptance Models (TAM) yang diperkenalkan oleh Davis (1989), sebuah penerimaan individu terhadap teknologi komputer yang didasarkan pada dua keyakinan, yaitu:

a. Perceived Usefulness (PU), yaitu tingkatan pada seseorang berfikir bahwa menggunakan suatu sistem akan meningkatkan kinerjanya.

b. Perceived Ease of Use (PEOU), yaitu tingkatan seseorang mempercayai bahwa menggunakan teknologi hanya memerlukan sedikit usaha.

\section{Website Service Quality}

Website Service Quality atau yang juga dikenal dengan E-ServQual dikembangkan untuk mengevaluasi suatu pelayanan yang diberikan pada jaringan internet. E-Service Quality didefinisikan sebagai perluasan dari kemampuan suatu situs untuk memfasilitasi kegiatan belanja, pembelian, dan distribusi secara efektif dan efisien. Adapun dimensi-dimensi dari E-Service Quality menurut R. B. Chase, K. Blackmon, and A. Roth (2004.) meliputi, reliabilitas (reliability), daya tanggap (responsiveness), akses (access), fleksibilitas (flexibility), navigasi yang mudah (ease of navigation), efisiensi (efficiency), kepercayaan (trust), keamanan privasi (security privacy), pengetahuan tentang harga (price knowledge), segi astetik situs (site aesthetics), personalisasi (customization /personalization).

\section{Specific Holdup Cost}

Dalam proses pembelian yang dilakukan oleh konsumen melalui media internet (online shopping), konsumen memerlukan usaha, waktu, dan biaya dalam proses pembelian sebuah barang/jasa. Usaha dan waktu sebagai salah satu biaya yang harus dikeluarkan oleh konsumen untuk dapat memenuhi kebutuhannya dengan melakukan pembelian pada media internet. Pada penelitian
G.T.Lin and C. Sun (2008.), dijelaskan bahwa biaya-biaya spesifik yang harus dikeluarkan konsumen pada saat berbelanja online adalah dengan menyediakan waktu dan usaha ketika mempelajari dan mencari informasi dari sebuah situs. Atas pengalaman yang dirasakan oleh konsumen dalam penggunaan sebuah situs, maka dapat terbentuk sebuah sikap untuk dapat menggunakan situs tersebut kembali.

\section{METODE PENELITIAN}

Dalam penelitian ini menggunakan jenis penelitian sebab akibat (causal research) dengan teknik pengambilan sampel menggunakan teknik purposive sampling, yaitu merupakan teknik pengambilan sampel yang digunakan peneliti jika peneliti mempunyai pertimbangan - pertimbangan tertentu dalam pengambilan sampel atau penentuan sampel untuk tujuan tertentu (Riduan, 2014:63). Maka dari itu, sampel dalam penelitian ini sebanyak 95 mahasiswa dengan beberapa pertimbangan sebagai berikut:

a. Mahasiswa yang masih terdaftar sebagai mahasiswa aktif..

b. Mahasiswa yang pernah menggunakan dan berbelanja di Shopee.

c.

Dalam penelitian ini, menggunakan analisis regresi linier berganda (multiple regression analysis). Berdasarkan hipotesis penelitian ini, untuk menguji dua atau lebih variabel bebas (independent) terhadap satu variabel terikat (dependent), maka menurut Robert D. Mason dan Douglas A. Lind (1999:102), pengujian menggunakan rumus atau persamaan sebagai berikut :

$$
\mathbf{Y}=\mathbf{a}+\mathbf{b}_{1} \mathbf{X}_{1}+\mathbf{b}_{2} \mathbf{X}_{2}+\mathbf{b}_{3} \mathbf{X}_{3}+\mathbf{e}
$$

\section{HASIL PENELITIAN DAN PEMBAHASAN}

Pada penelitian ini, untuk mengetahui pengaruh variabel Technology Acceptance Factors (X1), Website Service Quality (X2), Specific Holdup Cost, Customer Loyalty (X3) sebagai variabel bebas (independent) terhadap Loyalitas Pelanggan (Y) sebagai variabel terikat (dependent) dilakukan dengan menggunakan analisis regresi linier berganda (multiple regression analysis). Selain itu, dari analisis linear berganda tersebut juga diperoleh koefisien regresi yang menunjukan arah hubungan dari variabel bebas (independent) tersebut dengan variabel terikat (dependent). 
Berikut hasil pengujian regresi berganda yang disajikan pada tabel 1 dibawah ini :

Tabel 1. Coefficients Regresi (uji t)

\begin{tabular}{|c|c|c|c|c|c|c|}
\hline \multirow{2}{*}{\multicolumn{2}{|c|}{ Model }} & \multicolumn{2}{|c|}{$\begin{array}{l}\text { Unstandardized } \\
\text { Coefficients }\end{array}$} & \multirow{2}{*}{$\begin{array}{c}\text { Standardized } \\
\text { Coefficients } \\
\text { Beta } \\
\end{array}$} & \multirow[b]{2}{*}{$\mathrm{T}$} & \multirow[b]{2}{*}{ Sig. } \\
\hline & & B & $\begin{array}{l}\text { Std. } \\
\text { Error }\end{array}$ & & & \\
\hline 1 & (Constant) & 2,575 & 0,581 & & 4,434 & 0,000 \\
\hline & TAF & 0,114 & 0,078 & 0,145 & 1,459 & 0,148 \\
\hline & WSQ & $-0,092$ & 0,128 & $-0,072$ & $-0,718$ & 0,475 \\
\hline & $\overline{\mathrm{SHC}}$ & 0,241 & 0,064 & 0,366 & 3,750 & 0,000 \\
\hline
\end{tabular}

Sumber : Output SPSS, 2019

Berdasarkan hasil perhitungan pada tabel 1 . di atas, maka dapat disusun persamaan regresi sebagai berikut :

$$
Y=2,575+0,114-0,092+0,241+0,581
$$

Dari persamaan regresi berganda tersebut dapat diinterpretasikan sebagai berikut :

1. Nilai konstanta bernilai positif, hal tersebut menunjukkan jika Technology Acceptance Factors, Website Service Quality, Specific Holdup Cost, Customer Loyalty tidak berubah, maka Loyalitas Pelanggan akan memiliki nilai sebesar 2,575.

2. Nilai koefisien regresi Technology Acceptance Factors $\left(b_{1}\right)$ sebesar 0,114 yang menunjukkan bahwa terdapat arah hubungan yang positif (searah), artinya, apabila $T A F$ mengalami kenaikan 1 satuan, maka loyalitas pelanggan akan meningkat sebesar 0,114 dengan asumsi variabel lainnya dianggap tetap, namun kondisi tersebut tidak dapat direpresentasikan, karena hasil pengujian menunjukkan bahwa TAF tidak memiliki pengaruh yang signifikan.

3. Nilai koefisien regresi Website Service Quality $\left(b_{2}\right)$ sebesar -0,092 yang menunjukkan bahwa WSQ memiliki arah hubungan yang negatif (tidak searah), artinya, apabila WSQ mengalami kenaikan 1 satuan, maka loyalitas pelanggan akan menurun sebesar 0,092 dengan asumsi variabel lainnya dianggap tetap. namun kondisi tersebut juga tidak dapat direpresentasikan, karena hasil pengujian menunjukkan bahwa TAF tidak memiliki pengaruh yang signifikan.

4. Nilai koefisien regresi Specific Holdup Cost $\left(b_{3}\right)$ sebesar 0,241 yang menunjukkan bahwa terdapat arah hubungan yang positif (searah), artinya apabila SHC mengalami kenaikan 1 satuan, maka loyalitas pelanggan akan meningkat sebesar 0,241 dengan asumsi variabel lainnya dianggap konstan atau tetap.
Pengaruh Technology Acceptance Factors (X1) terhadap Loyalitas Pelanggan (Y) secara parsial

Dari hasil uji regresi linier berganda (tabel 1), diperoleh hasil nilai $t_{\text {hitung }}$ untuk pengaruh variabel TAF secara parsial terhadap variabel Loyalitas Pelanggan sebesar 1,459 , sedangkan nilai $t_{\text {tabel }}$ dengan taraf kepercayaan $95 \%(\alpha=0,05)$ diperoleh nilai 1,990 yang mana apabila dibandingkan, nilai $\mathrm{t}_{\text {hitung }}$ lebih kecil dari nilai $\mathrm{t}_{\text {tabel }}$ atau 1,459 < 1,990 dengan nilai sig.t sebesar 0,148 yang mana lebih besar dibandingkan 0,05 atau 0,148>0,05.

Berdasarkan hasil yang diperoleh dari uji regresi linier berganda dengan membandingkan nilai $t_{\text {hitung }}$ dan $t_{\text {tabel }}$ serta nilai sig.t sesuai ketentuan kriteria pengujian dalam penelitian ini, maka dapat dikatakan bahwa tidak terdapat pengaruh signifikan secara parsial variabel TAF terhadap variabel Loyalitas Pelanggan. Sedangkan Sedangkan Koefisien B (intersep) regresi menunjukkan nilai positif sebesar 0,114 , yang mana hal tersebut menunjukkan pola kausalitas yang searah antara variabel TAF dengan Loyalitas Pelanggan. Besar pengaruhnya (nilai Beta) sebesar 0,145 atau $14,5 \%$ yang dapat diinterpretasikan bahwa Loyalitas Pelanggan ditentukan oleh variasi nilai TAF sebesar $14,5 \%$.

\section{Pengaruh Website Service Quality (X2) terhadap Loyalitas Pelanggan (Y) secara parsial}

Dari hasil uji regresi linier berganda (tabel 1), diperoleh hasil nilai $t_{\text {hitung }}$ untuk pengaruh variabel WSQ secara parsial terhadap Loyalitas Pelanggan sebesar $-0,718$, sedangkan nilai $t_{\text {tabel }}$ dengan taraf kepercayaan 95\% $(\alpha=0,05)$ diperoleh nilai 1,990 yang mana apabila dibandingkan, nilai $t_{\text {hitung }}$ lebih besar dari nilai $t_{\text {tabel }}$ atau $-0,718>1,990$ dengan nilai sig.t sebesar 0,475 yang mana lebih besar dibandingkan 0,05 atau 0,475>0,05.

Berdasarkan hasil yang diperoleh maka dapat dikatakan bahwa tidak terdapat pengaruh signifikan secara parsial variabel WSQ terhadap variabel Loyalitas Pelanggan. Sedangkan Koefieien B (intersep) regresi menunjukan nilai negatif sebesar -0,092, hal tersebut menunjukan pola kausalitas yang tidak searah antara WSQ dan Loyalitas Pelanggan. Nilai Beta yang diperoleh sebesar 0,072 atau $7,2 \%$ yang dapat diinterpretasikan bahwa Loyalitas Pelanggan ditentukan oleh variabel WSQ sebesar 7,2\%.

\section{Pengaruh Specific Holdup Cost (X3) terhadap Loyalitas Pelanggan (Y) secara parsial}

Dari hasil uji regresi linier berganda (tabel 1), diperoleh hasil nilai $t_{\text {hitung }}$ untuk variabel SHC secara parsial terhadap variabel Loyalitas Pelanggan sebesar 3,750, sedangkan nilai $t_{\text {tabel }}$ 
https://ejurnal.stimi-bjm.ac.id/index.php/JRIMK

dengan taraf kepercayaan $95 \%(\alpha=0,05)$ diperoleh nilai 1,990 yang mana apabila dibandingkan, nilai $\mathrm{t}_{\text {hitung }}$ lebih besar dari nilai $\mathrm{t}_{\text {tabel }}$ atau 3,750 > 1,990 dengan nilai sig.t sebesar 0,000 yang mana lebih kecil dibandingkan 0,05 atau 0,000 < 0,05.

Berdasarkan hasil yang diperoleh dari uji regresi linier berganda dengan membandingkan nilai $\mathrm{t}_{\text {hitung }}$ dan $\mathrm{t}_{\text {tabel }}$ serta nilai sig. $t$ sesuai ketentuan kriteria pengujian dalam penelitian ini, maka dapat dikatakan bahwa terdapat pengaruh signifikan secara parsial variabel SHC terhadap variabel Loyalitas Pelanggan. Sedangkan Sedangkan Koefisien B (intersep) regresi menunjukkan nilai positif sebesar 0,241, yang mana hal tersebut menunjukkan pola kausalitas yang searah antara variabel SHC dengan Loyalitas Pelanggan. Besar pengaruhnya (nilai Beta) sebesar 0,366 atau 36,6\% yang dapat diinterpretasikan bahwa Loyalitas Pelanggan ditentukan oleh variasi nilai SHC sebesar $36,6 \%$.

Pengaruh Technology Acceptance Factors (X1), Website Service Quality (X2), Specific Holdup Cost (X3) terhadap Loyalitas Pelanggan secara simultan

Hasil uji regresi linier berganda untuk menguji pengaruh variabel independent terhadap variabel dependent secara simultan ditunjukan pada tabel 2 dibawah ini:

Tabel 2. Hasil Uji F (Anova)

\begin{tabular}{lccccc}
\hline & Sum of & \multicolumn{4}{c}{ Mean } \\
Model & Squares & df & Square & $F$ & Sig. \\
\hline Regression & 1,102 & 3 & 0,367 & 5,409 & $0,002^{\mathrm{b}}$ \\
Residual & 6,183 & 91 & 0,068 & & \\
Total & 7,285 & 94 & & & \\
\hline
\end{tabular}

Sumber : Output SPSS, 2019

Dari hasil uji regresi linier berganda (tabel 2), diperoleh hasil nilai $\mathrm{F}_{\text {hitung }}$ untuk pengaruh Technology Acceptance Factors, Website Service Quality, Specific Holdup Cost terhadap Loyalitas Pelanggan sebesar 5,409, sedangkan nilai $F_{\text {tabel }}$ dengan taraf kepercayaan 95\% $(\alpha=0,05)$ diperoleh nilai 2,70 yang mana apabila dibandingkan, nilai $F_{\text {hitung }}$ lebih besar dari nilai $F_{\text {tabel }}$ atau 5,409 $>2,70$ dengan nilai sig.F sebesar 0,002 yang mana lebih kecil dibandingkan 0,05 atau 0,002 $<0,05$, maka dapat dikatakan bahwa terdapat pengaruh signifikan secara simultan Technology Acceptance Factors, Website Service Quality, Specific Holdup Cost terhadap Loyalitas Pelanggan.

Interpretasi pengaruh secara simultan regresi berganda dilakukan dengan cara mendefinisikan nilai $R$ (Regresi Ganda), $R$ Square (Koefisien Determinasi) serta Adjusted $R$ Square (koefisien determinasi yang disesuaikan). Berikut nilai $R$ (Regresi Ganda), $R$ Square (koefisien determinasi) serta Adjusted $R$ Square (koefisien determinasi yang disesuaikan) yang ditunjukkan pada tabel 3 dibawah ini:

Tabel 3. Nilai $R, R$ Square \& Aj. $R$ Square

\begin{tabular}{|c|c|c|c|c|}
\hline Model & R & R Square & $\begin{array}{c}\text { Adjusted R } \\
\text { Square }\end{array}$ & $\begin{array}{l}\text { Std. Error of the } \\
\text { Estimate }\end{array}$ \\
\hline 1 & $0,389^{\mathrm{a}}$ & 0,151 & 0,123 & 0,26066 \\
\hline
\end{tabular}

Sumber : Output SPSS, 2019

Sugiono (2009) mengemukakan kriteria kekuatan korelasi antar variabel yang mana jika nilai $(R)$ berada diantara nilai sebagai berikut :

Tabel 4. Kriteria Kekuatan Korelasi antar Variabel

\begin{tabular}{ccc|l}
\hline & & 0 & Tidak ada korelasi antara dua variabel \\
\hline$>0$ & sampai & 0,25 & Korelasi sangat lemah \\
\hline$>0,25$ & sampai & 0,50 & Korelasi cukup kuat \\
\hline$>0,50$ & sampai & 0,75 & Korelasi kuat \\
\hline$>0,75$ & sampai & 0,99 & Korelasi sangat kuat \\
\hline \multicolumn{3}{r}{1} & Korelasi sempurna \\
\hline
\end{tabular}

Pada penelitian ini, diperoleh hasil $R$ (korelasi) sebesar 0,389, sehingga nilai $R$ yang diperoleh menunjukkan korelasi ganda variabel Technology Acceptance Factors, Website Service Quality, Specific Holdup Cost terhadap Loyalitas Pelanggan memiliki korelasi yang cukup kuat.

Nilai $R$ Square atau koefisien determinasi sebesar 0,151 atau $15,1 \%$, namun untuk regresi berganda lebih baik digunakan nilai Adjusted $R$ Square yang mana selalu lebih kecil dari nilai $R$ Square dalam menginterpretasikan besar pengaruh secara simultan. Nilai Adjusted $R$ Square menunjukkan 0,123 atau $12,3 \%$ variabel dari loyalitas pelanggan dapat dijelaskan oleh variabel dari Technology Acceptance Factors, Website Service Quality, Specific Holdup Cost, sedangkan selebihnya $(100 \%-12,3 \%)$ yaitu $87,7 \%$ dijelaskan oleh variabel lain diluar model penelitian. Koefisien pengaruh secara simultan positif yang menunjukkan bahwa secara bersama - sama (simultan) naiknya nilai dari Technology Acceptance Factors, Website Service Quality, Specific Holdup Cost akan meningkatkan Loyalitas Pelanggan, sebaliknya turunnya nilai dari Technology Acceptance Factors, Website Service Quality, Specific Holdup Cost secara bersamaan, maka akan menurunkan Loyalitas Pelanggan.

\section{KESIMPULAN}

Berdasarkan hasil analisis yang dilakukan mengenai pengaruh Technology Acceptance Factors, Website Service Quality, dan Specific Holdup Cost terhadap Loyalitas Pelanggan, maka dapat ditarik kesimpulan sebagai berikut :

1. Technology Acceptance Factors tidak memiliki pengaruh signifikan secara parsial terhadap loyalitas pelanggan dari kalangan mahasiswa Politeknik Kotabaru. 
2. Website Service Quality tidak memiliki pengaruh signifikan secara parsial terhadap loyalitas pelanggan dari kalangan mahasiswa Politeknik Kotabaru.

3. Specific Holdup Cost mahasiswa memiliki pengaruh signifikan dan positif secara parsial terhadap loyalitas pelanggan dikalangan mahasiswa Politeknik Kotabaru.

4. Technology Acceptance Factors, Website Service Quality, dan Specific Holdup Cost memiliki pengaruh signifikan dan positif secara simultan terhadap loyalitas pelanggan dikalangan mahasiswa Politeknik Kotabaru.

\section{DAFTAR PUSTAKA}

G.T.Lin and C.-C.Sun, "Factors influencing satisfaction and loyalty in online shopping an integrated model," Inst. Technol. Manag. Natl. Chiao Tung Univ. Hsin Chuh City Taiwan, pp. 458-475, 2008.

H. Chaang Iuan and L. Yi Ling, "The development of an e-travel service quality scale," vol. 28 , no. 6, pp. 1434-1449, 2007.

J. Griffin. (2005). Menumbuhkan dan Mempertahankan Kesetiaan Pelanggan. Jakarta: Erlangga.

J. Fernando, T. D. Desyana, and A. Christian, "Pengaruh loyalitas Pelanggan Terhadap Berbelanja Secara Online," Bina Nusant., 2014.

Kotler and Keller. (2007). Manajemen Pemasaran, Edisi 12. Jakarta: PT. Indeks
N. M. S. Anggraeni and N. N. K. Yasa, "E-Service Quality terhadap Kepuasan dan Loyalitas Pelanggan dalam Penggunaan Internet Banking," vol. 16, no. 2, pp. 293-306, 2012.

Purnomo, Bambang Eko Hadi. (2015). Analisis Faktor-Faktor Yang Mempengaruhi Kepuasan Dan Loyalitas Pelanggan Pada Online Shopping (Studi Kasus : Tiket.Com). Fakultas Teknologi Informasi Institut Teknologi Sepuluh Nopember

R. B. Chase, K. Blackmon, and A. . Roth, "A Tale of Two Countries Conservatism, Service Quality, and Feedback on Customer Satisfaction," vol. 6, no. 3, pp. 212-231, 2004.

Riduan. (2010). Metode dan Teknik Menyusun Tesis, Edisi Kesepuluh. Bandung: ALFABETA

Robert D. Mason dan Douglas A. Lind. (1996). Teknik Statistika untuk Bisnis dan Ekonomi, Edisi Kesembilan. Alih bahasa, Wikarya, U., Soetjipto, W., \& Sugiharso (1999). Jakarta: Erlangga.

Sugiyono. (2009). Metode Penelitian Kuantitatif, Kualitatif dan Research \& Development. Bandung: Alfabeta.

\section{Profil Penulis}

Dayat Ikhsan H., S. Pd., M.A.B., Program Studi Administrasi Bisnis, Politeknik Kotabaru Jl. Raya Stagen Km. 9,5 Kotabaru Email : diksan.poltek.ktb@gmail.com 